Article

\title{
Performance Analysis of Combined Cycle with Air Breathing Derivative Gas Turbine, Heat Recovery Steam Generator, and Steam Turbine as LNG Tanker Main Engine Propulsion System
}

\author{
Wahyu Nirbito *, Muhammad Arif Budiyanto $@$ and Robby Muliadi \\ Department of Mechanical Engineering, Universitas Indonesia, Kampus Baru UI, Jawa Barat 16424, Indonesia; \\ arif@eng.ui.ac.id (M.A.B.); bitomesin76@gmail.com (R.M.) \\ * Correspondence: bito@eng.ui.ac.id
}

Received: 1 September 2020; Accepted: 14 September 2020; Published: 20 September 2020

\begin{abstract}
This study explains the performance analysis of a propulsion system engine of an LNG tanker using a combined cycle whose components are gas turbine, steam turbine, and heat recovery steam generator. The researches are to determine the total resistance of an LNG tanker with a capacity of $125,000 \mathrm{~m}^{3}$ by using the Maxsurf Resistance 20 software, as well as to design the propulsion system to meet the required power from the resistance by using the Cycle-Tempo 5.0 software. The simulation results indicate a maximum power of the system of about $28,122.23 \mathrm{~kW}$ with a fuel consumption of about $1.173 \mathrm{~kg} / \mathrm{s}$ and a system efficiency of about $48.49 \%$ in fully loaded conditions. The ship speed can reach up to 20.67 knots.
\end{abstract}

Keywords: LNG tanker; combined cycle; propulsion main engine

\section{Introduction}

Transportation of natural gas between islands can be done in various ways, such as through transmission pipes or by using sea transportation modes [1]. The transportation of natural gas using pipes has several limitations; namely, limited mobility requires a large investment; handling the compressor system is quite complicated, i.e. the further the supplied distance, the bigger compressor must be used; and the environmental safety management is quite difficult considering that the pressure in the pipeline is very high so that a little leak can be fatal to the environment [2-4]. Therefore, for cross-sea transportation with long distances, ships are chosen as the mode of transportation [5]. In its development, natural gas transportation using ships is divided into two broad lines, namely, transporting natural gas in the gas phase/compressed natural gas (CNG) and in the liquid phase/liquefied natural gas (LNG). The disadvantage of transporting in the gas phase is the need for pressure vessels that are able to withstand high pressures and large volumes, so in general, the transportation of natural gas through ships is done by the liquid/LNG phase, namely, by maintaining a charged temperature that causes the natural gas to be in the liquid phase [6-10]. LNG tankers are an option for transporting large amounts of natural gas for long distances [11]. At present, LNG tankers of various types and sizes are widely available in the world. Based on data from the International Gas Union (IGN), there were 373 active ships with capacities above $30,000 \mathrm{~m}^{3}$ in 2015 , and as many as 28 ships are under construction [12]. The value of charter vessels dropping to $\$ 40,000 /$ day in the third quarter of 2014 due to the decreased number of cross-Pacific-Atlantic shipments and the construction of large vessels in 2015 caused the LNG freight market share to decline [13]. Old ships that still use the inefficient steam turbine propulsion system must be able to compete with ships that use new propulsion systems that are far more efficient [14]. This condition encourages owners to build ships with more efficient propulsion 
systems. One of the factors that influence the level of efficiency of gas transportation using LNG tankers is the propulsion system used. Currently, LNG tankers in the world generally still use a steam turbine with boilers that use fuel from boil-off gas [15-18]. Several alternative propulsion systems have been developed by engineers to increase the efficiency value of the main engine driving LNG tankers, such as the dual-fuel diesel engine (DFDE) [19] and the combined cycle [20-22]. The majority of active LNG ships in the world currently use a steam turbine propulsion system with a low level of efficiency; therefore, today engineers continue to develop an efficient propulsion system at the range of the power required by LNG ships. Propulsion systems with diesel engines and ones with combined cycles have different dimensions due to the different equipment components are used to support the performance of the engines $[16,23]$. Large and heavy engines cause the ship to lose volume and weight that could otherwise be used to transport cargo. This can be circumvented by designing machines that also produce the right power but are smaller and lighter with an efficient arrangement of the engine room $[23,24]$. Combined cycle is an alternative propulsion system that can be applied to LNG tankers engine of power between 20 to $50 \mathrm{MW}$, by considering its overall efficiency. It can be seen that the combined cycle systems have higher total efficiency than other propulsion system engines. Currently, large-capacity LNG tankers require at least $25 \mathrm{MW}$ for propulsion and auxiliary systems on board [25-30]. Therefore, further studies are needed for a marine combined-cycle gas steam turbine power plant. This paper has two main objectives, namely, designing the propulsion system in an LNG tanker with a combined-cycle propulsion system and calculating the performance of the combined-cycle system with an air-breathing derivative gas turbine, heat recovery steam generator (HRSG), and steam turbine as the LNG tanker's main engine propulsion system. Based on these objectives, the formulated problem is to design combined gas-electric steam (COGES) propulsion systems on LNG tankers with engine power requirements related to ship resistance at a certain speed, and to determine the tools needed to support the performance of the propulsion system.

\section{Methodology}

\subsection{Research Stages}

The following is a design methodology that was carried out in this design:

1. Field Study

Conduct a search and study of LNG tankers that would be implemented using the combined-cycle gas steam turbine propulsion system for the power requirements of the propulsion system and the ship's auxiliary systems.

2. Literature Study

Learn the basics of propulsion systems using a combined-cycle gas steam turbine and the tools needed to support the operation of the propulsion system.

\section{Problem Statement}

Identify the propulsion power requirements of the ship to be designed for the propulsion system. Determine the tools needed to support the performance of the propulsion system.

4. Design and Analysis

Design and calculate the design of the propulsion system with the parameters available from the ship to be applied to the propulsion system, to get the power in accordance with the needs of the ship. In this design study, the Maxsurf Resistance 20 software was used to obtain the resistance value using this method for each desired value of the ship's speed. This software can estimate resistance and power requirements for ships designed using industry-standard prediction techniques. The data input required from this software is the shape of the hull of the ship. In this case, the main dimensions of the hull are shown in Table 1. Apart from determining the ship's power requirements, the analysis of the thermodynamic calculations of the propulsion system was designed using the Cycle-Tempo 5.1 software. In simulations using the software, several parameters are needed to simulate a steam turbine, 
such as pressure, temperature, and mass flow rate of the steam, for the calculation of the isentropic efficiency of the steam turbine component is used based on relevant references.

Table 1. LNG tankers with a capacity of $125,000 \mathrm{~m}^{3}$.

\begin{tabular}{cc}
\hline Ship Name & LNG Aquarius \\
\hline LOA & $285.3 \mathrm{~m}$ \\
LBP & $273.4 \mathrm{~m}$ \\
Beam & $43.74 \mathrm{~m}$ \\
Depth to main deck & $24.99 \mathrm{~m}$ \\
Full-load draft & $10.97 \mathrm{~m}$ \\
Scantling draft & $11.53 \mathrm{~m}$ \\
Engine type & Steam turbine \\
Number of propellers & 1 \\
Trial speed & 20.4 knots \\
Service speed & 19.5 knots \\
Cargo tank capacity & $126,400 \mathrm{~m}^{3}$ \\
(-160 ${ }^{\circ}$ C) & Spherical aluminum \\
Tank design & 31 \\
Crew number &
\end{tabular}

\subsection{Data Used}

In this design study, some reference data needed to get the appropriate design of the system were as follows:

\section{LNG Tanker}

Table 1 shows the specification of the LNG tanker with a capacity of 125,000 $\mathrm{m}^{3}$ [31].

2. Ship Load Data

Data of the shipload were obtained from the operation report of the comparison ship, LNG Aquarius, as shown in Table 2 [32].

Table 2. LNG cargo handling averages.

\begin{tabular}{cc}
\hline Cargo Aboard & \\
\hline After loading & $125,400 \mathrm{~m}^{3}$ \\
Before discharge & $123,400 \mathrm{~m}^{3}$ \\
Heel aboard & $1900 \mathrm{~m}^{3}$ \\
After loading & $600 \mathrm{~m}^{3}$ \\
Before discharge & $124,800 \mathrm{~m}^{3}$ \\
Cargo loaded & $121,500 \mathrm{~m}^{3}$ \\
Cargo discharged & \\
Boil-off & $2,000 \mathrm{~m}^{3}$ \\
Loaded leg & $1,300 \mathrm{~m}^{3}$ \\
Ballast leg &
\end{tabular}

\section{Shipping Conditions}

The LNG tanker propulsion system in this study is designed for LNG shipping between Bontang, East Kalimantan to Japan. The assumption of the environmental conditions of the journey are shown in Table 3 [33]: 
Table 3. Assumed environmental shipping conditions.

\begin{tabular}{cc}
\hline Air Temperature & $\mathbf{2 7}{ }^{\circ} \mathbf{C}$ (Average Daily Temperature at Bontang) \\
\hline Sea water temperature & $28{ }^{\circ} \mathrm{C}$ \\
Environmental pressure & $1.01 \mathrm{bar}$ \\
Mileage & 2,400 nautical miles \\
Total sailing hours & 316.2 \\
Total sailing days & 13.2 \\
\hline
\end{tabular}

\subsection{Calculation of Ship Resistance}

In this design, we needed some data to get an appropriate design, including the amount of power needed by the ship to go at the required speed, so the calculation of the value of the obstacle for $125,000 \mathrm{~m}^{3}$ LNG tankers was needed. In this design study, the application of Maxsurf Resistance 20 software provided the steps to be followed for determining the value of the ship's resistance [34]. Figure 1 shows a graph of the results of a resistance simulation using the Holtrop method with a speed range between 0 and 22.5 knots.

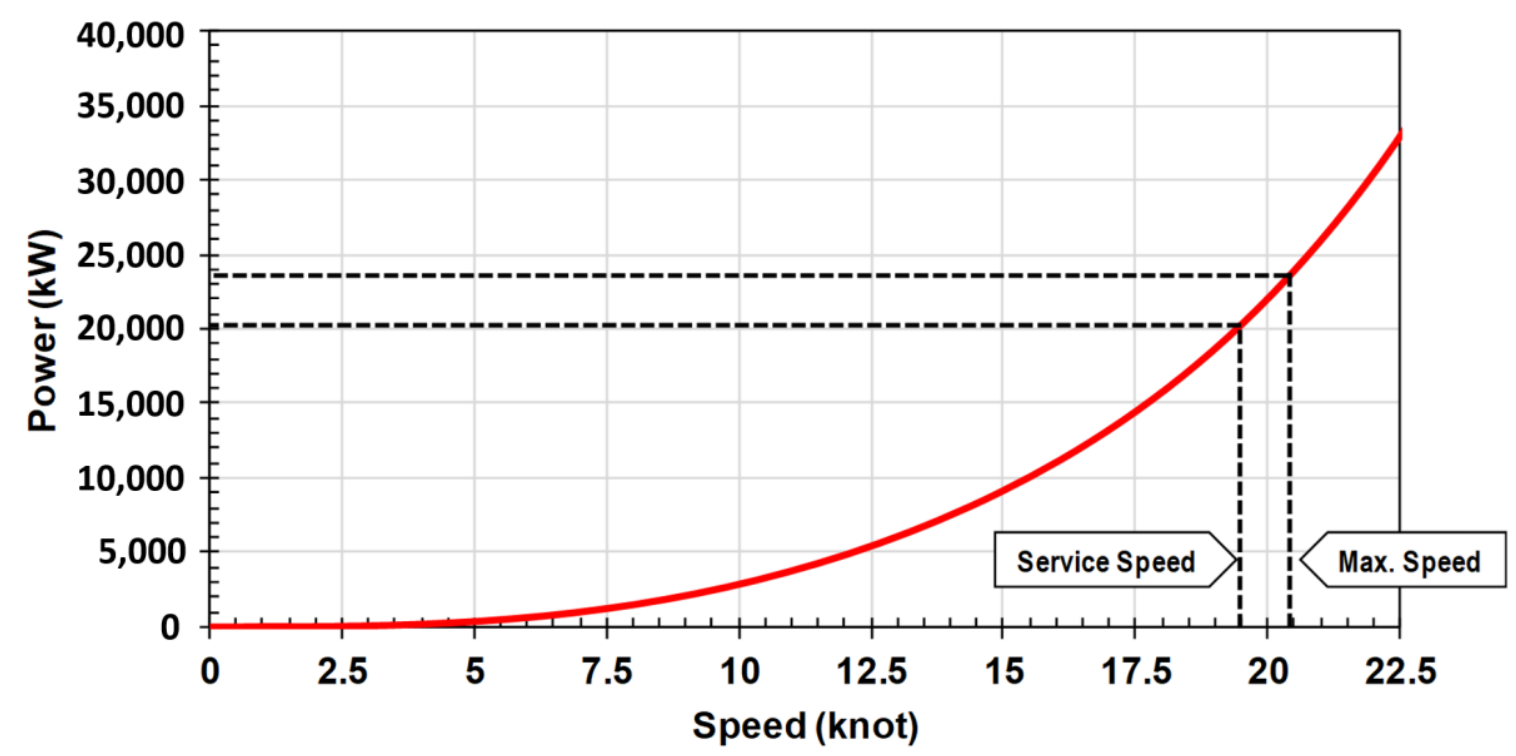

Figure 1. Power prediction using Holtrop methods.

\subsection{Design of Combined-Cycle Propulsion System}

After getting the data resistance of the LNG tanker, which would be designed to be able to determine the amount of power for ship propulsion, the next step was to design a propulsion system to meet the power requirements of the ship. The design of the combined-cycle system was done using the Cycle-Tempo software so that each component of the designed system could be connected and in accordance with the desired results. Figure 2 presents a scheme of this propulsion system. The processes in the systems are shown in Figure 2 as well. The design of this system consisted of gas turbine components, which consisted of (3) compressor, (4) combustion chamber, and (5) turbine, using fuel sourced from (1) the fuel source. Then this component was directly connected by the shaft to rotate the electric generator. 


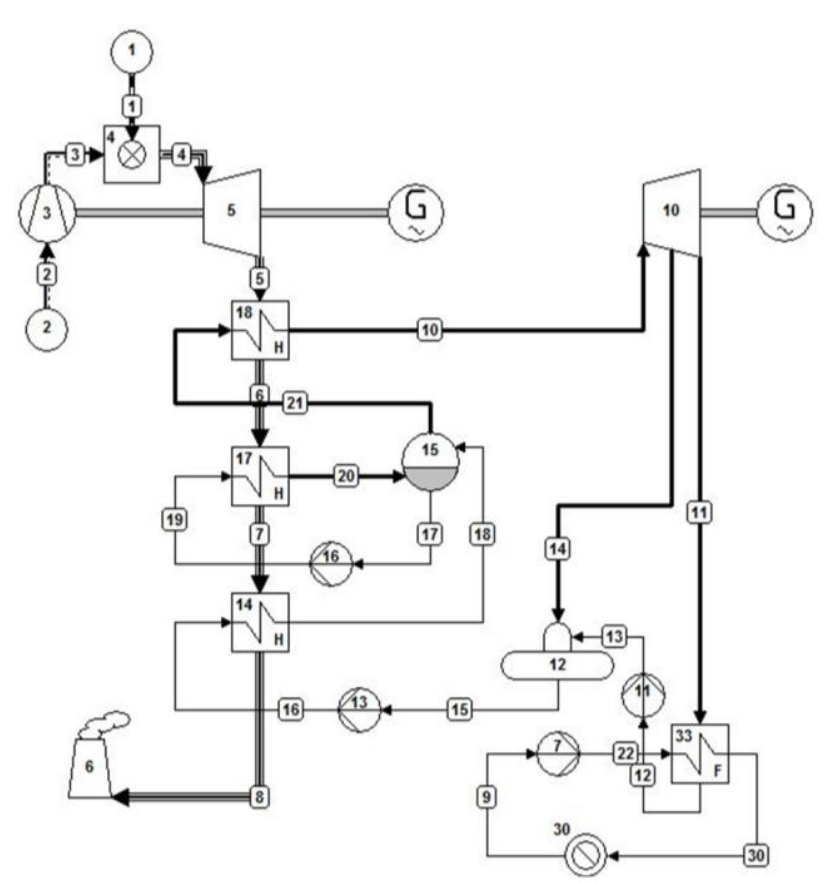

Figure Information:

1. Fuel source

2. Fresh air

3. Compressor

4. Combustion chamber

5. Turbine

6. Funnel

7. Pump

8. Gas turbine exhaust gas pipe

9. Sea water cooling transmission pipe

10. Superheated steam transmission pipe

11. Pump

12. Heat recovery steam generator

13. Steam turbine condensate transmission pipe

14. Economizer

15. Steam drum

16. Pump

17. Evaporator

18. Superheater

19. Steam turbine exhaust gas outlet pipe

20. Steam inlet pipe

21. Steam to superheater transmission pipe

22. Sea water inlet pipe

30 . Sea water cooling system

33. Steam condensing cooler

Figure 2. Schematic of a combined-cycle propulsion system.

The working fluid, after coming out of the steam turbine, was still in the saturated vapor phase (saturated steam). Then this fluid entered (33) the condenser, which then turned into saturated liquid phase. To change the phase of the working fluid, the condenser got the cooling medium from (30) the sea water pump. Then the water that had been used as a cooler was discharged into the environment. HRSG is a device that utilizes heat energy from gas turbine flue gas to be used as a source of steam turbine cycle energy. The working fluid was pumped after it exited the condenser and then entered (14) the economizer, where the working fluid temperature was increased. Then it was forwarded to (17) the evaporator where the working fluid phase was changed into saturated steam. Then the steam entered (18) the superheater where the saturated steam phase changed to superheated steam. After that the working fluid, i.e. superheated steam, entered the steam turbine to be converted into mechanical energy to turn the electric generator. After leaving the steam turbine, the working fluid returned to the condenser.

To be able to simulate the design of a combined-cycle propulsion system, several parameter values of the system components to be designed were needed, including:

1. Fuel

The fuel used was natural gas from boil-off cargo gas that was transported. The carried cargo was natural gas from a liquefaction plant in Bontang, East Kalimantan, whose composition and characteristics are shown in Table 4.

Table 4. The composition and characteristics of natural gas [35].

\begin{tabular}{cc}
\hline $\mathrm{CH}_{4}$ & $91.20 \%$ \\
$\mathrm{C}_{2} \mathrm{H}_{6}$ & $5.50 \%$ \\
$\mathrm{C}_{3} \mathrm{H}_{8}$ & $2.40 \%$ \\
$\mathrm{C}_{4} \mathrm{H}_{10}$ & $0.90 \%$ \\
$\mathrm{O}_{2}$ & $0.10 \%$ \\
$\mathrm{~N}_{2}$ & $0.00 \%$ \\
Lower heating value (LHV) & $49,426.97 \mathrm{~kJ} / \mathrm{kg}$ \\
Liquid density (LNG) & $456 \mathrm{~kg} / \mathrm{m}^{3}$ \\
Gas density (CNG) & $0.801 \mathrm{~kg} / \mathrm{m}^{3}\left(0{ }^{\circ} \mathrm{C}, 1 \mathrm{~atm}\right)$ \\
Expansion ratio (Gas/Liq) & $568 \mathrm{~m}^{3}(\mathrm{gas}) / \mathrm{m}^{3}(\mathrm{liq})\left(0^{\circ} \mathrm{C}, 1 \mathrm{~atm}\right)$ \\
\hline
\end{tabular}




\section{Gas Turbine}

The basis of the selection of the gas turbine specifications used in this design study was the output power, based on the availability of gas turbine types on the market for the required power range. The appropriate gas turbine model was obtained as shown in Table 5. Data supporting the simulations in this design study used sources from a datasheet from the manufacturer, as well as data sourced from research results. In operation, the gas turbine must be within the operating range of the gas turbine to prevent the condition of chocking and surging. Therefore, in this simulation, the gas turbine operation was adjusted to the performance characteristic map issued by the manufacturer.

Table 5. Gas turbine specifications [36].

\begin{tabular}{cc}
\hline Model & LM 2500 \\
\hline Manufacturer & General Electric \\
Power ISO condition $(100 \%$ load $)$ & $25 \mathrm{MW}$ \\
Power ambient condition $\left(27^{\circ} \mathrm{C}, 1.01 \mathrm{bar}\right)$ & $22.8 \mathrm{MW}$ \\
Fuel & Natural gas \\
Exhaust gas temperature $(100 \%$ load $)$ & $530{ }^{\circ} \mathrm{C}$ \\
Isentropic compressor efficiency & $70-87 \%$ \\
\hline
\end{tabular}

\section{Steam Turbine}

In simulations using the Cycle-Tempo software, several parameters were needed to do a steam turbine simulation, such as pressure, temperature, and mass vapor flow rate, for the calculation of the isentropic efficiency of the steam turbine component used based on the method set by general electric vapor pressure, which was chosen at 25 bar based on the recommendations of the results of an optimization study conducted by Følgesvold $[37,38]$. The specifications of the steam turbine used were an inlet vapor pressure of 25 bar and isentropic efficiency in the range of $0.8-0.88 \%$.

\section{HRSG}

The once-through steam generator (OTSG) HRSG was chosen as the most suitable choice for this simulation. This simulation included three main components of the HRSG, namely, superheater, evaporator, and economizer. In its operating conditions, the economizer is useful as a preheater to raise the temperature of the working fluid into the saturated liquid phase; then the working fluid enters the evaporator, then exits the phase change into saturated steam, then enters the superheater so it enters the boiler in the superheated steam phase. The parameters used in the simulation were the superheater temperature $\left(\Delta \mathrm{T}_{\mathrm{hi}}\right)$ was $30^{\circ} \mathrm{C}$ and the evaporator temperature $\left(\Delta \mathrm{T}_{\text {pinchpoint }}\right)$ was $25^{\circ} \mathrm{C}$.

An upper terminal difference temperature of $30^{\circ} \mathrm{C}$ and a pinch point of $25^{\circ} \mathrm{C}$ were chosen to provide enough energy to move the steam turbine cycle. According to Saravanamuttoo, this difference in temperature values was chosen to maintain the size and weight of the HRSG [39].

\section{Supporting Parameters}

Other supporting data used in the simulation were the isentropic pump efficiency used was $85 \%$, the deaerator pressure $\left(\mathrm{P}_{\text {in }}\right)$ was 2 bar, the pressure drop in the condenser was 0.1 bar, and the mechanical efficiency in the generator was $97.5 \%$.

\subsection{The Equation Used}

To be able to find out the appropriateness of the calculations using the Cycle-Tempo software with manual calculations, a manual calculation was made to load the system at maximum $(100 \%)$. The calculation of $T_{2}$ and $T_{3}$ under isentropic conditions in gas turbines is as follows:

$$
\frac{T_{2}}{T_{1}}=\left(\frac{P_{2}}{P_{1}}\right)^{\frac{k-1}{k}}
$$


where $T, P$, and $k$ are the temperature, pressure, and heat capacity ratio of the gas, respectively, and subscripts 1 and 2 denote the state before and after the isentropic compression process, respectively. The equations for the calculation of air mass flow rate $\left(m_{\text {air }}\right)$ and processes $(3-4)$, are the following:

$$
\begin{gathered}
\text { Qin }=m_{f u e l} \times L H V \\
Q_{\text {in }}=m_{\text {air }+f u e l} h_{3}-m_{\text {air }} h_{2}
\end{gathered}
$$

where $m_{\text {fiel }}$ and $L H V$ are the mass flow rate and lower heating value of the fuel, respectively, whereas $m_{\text {air }+f u e l}, m_{\text {air }}, h_{3}$, and $h_{2}$ are the mass flow rate of the air and fuel mixture, mass flow rate of the air, specific enthalpy of the air after the isobaric combustion process, and specific enthalpy of the air before the combustion, respectively. The values for enthalpies $h_{2}$ and $h_{3}$ were determined by interpolation of the relevance values in the table of water properties. The actual work of a gas turbine is:

$$
W_{\text {Gas Turbine }}=W_{\text {Steam Turbine }}-W_{\text {Compressor }}
$$

where $W_{\text {Gas Turbine }}$ and $W_{\text {Steam Turbine }}$ are the work output of the gas turbine and steam turbine, respectively, and $W_{\text {Compressor }}$ is the compressor work. The work of a steam turbine is:

$$
W_{\text {Steam Turbine }}=m\left(h_{4}-h_{3}\right)-v \Delta P
$$

where $m, h_{4}, h_{3}, v$, and $\Delta P$ are the mass flow rate of the working fluid, fluid enthalpy before entering the steam turbine, fluid enthalpy after exiting the turbine, specific volume of the working fluid, and pressure drop before and after the fluid enters the turbine, respectively. Looking for the value of the mass flow rate of the working fluid in the vapor cycle, the heating value $\left(Q_{i n}\right)$ was obtained from the heat recovery steam generator (HRSG), where this equation applied:

$$
\begin{gathered}
Q_{\text {Exhaust gas }}=Q_{\text {in }} \\
m_{\text {Exhaust gas }} c_{p} \Delta T=m_{\text {fluid }}\left(h_{4}-h_{3}\right)
\end{gathered}
$$

where $Q_{\text {Exhaust gas }}, m_{\text {Exhaust gas }}, c_{p}$, and $\Delta T$ are the heat output, mass flow rate, isobaric specific heat, and temperature difference of the exhaust gas from the gas turbine, respectively, whereas $Q_{i n}, m_{f l u i d}$, $h_{4}$, and $h_{3}$ are the heat input from the exhaust gas, mass flow rate, and specific enthalpies before and after the heating of the working fluid. The $h_{4}$ and $h_{3}$ values were obtained from the interpolation of the relevance values in the properties table for saturated water and superheated steam. Pump work calculation used the following equation:

$$
W_{\text {pumps }}=\frac{v \Delta P}{\eta}
$$

where $W_{\text {pump }}$ and $\eta$ are the work output and efficiency of the pump, respectively. The recommended pressure was 25 bar or $2500 \mathrm{kPa}$. Based on the literature, the $\eta$ (efficiency) of the pump was $87.5 \%$. Then the total work of the Rankine cycle is:

$$
W_{\text {Rankine }}=m_{\text {fluid }}(3460-2680)-W_{\text {pumps }}
$$

Therefore, we get the total system efficiency as:

$$
\eta_{\text {total }}=\frac{\text { Total Power }(k W)}{m_{f u e l}\left(\frac{k g}{s}\right) \times L H V\left(\frac{k J}{k g}\right)}
$$

There were result differences between the manual calculations and the calculations using the Cycle-Tempo software due to the less accuracy in manual calculations. The plotted values of the fluid 
properties, i.e. the enthalpy, specific heat capacities $c_{p}$ and $c_{v}$, were determined by interpolation in manual calculation whereas more accurate digital calculations were performed in the application software. Therefore, a slight difference in the values of the system power and system efficiency under the maximum loading conditions which result the total efficiency of the systems using empirical equations by manual calculation is $52.7 \%$, and based on the simulation software is $48.49 \%$.

\section{Results and Discussions}

\subsection{Thermodynamic Cycle Analysis}

Figure 3 is a T-s diagram of the actual gas turbine cycle with a dual shaft configuration. Point 1 is the environmental condition. Actual compressor work is illustrated by 1-2a. Then actual work of the gas turbine generator is illustrated by line $3-4 a$, and the work of the power turbine is represented by points $4 \mathrm{a}-5 \mathrm{a}$. The temperature of this cycle at the time of maximum loading ( $100 \%$ load) was $1215.87^{\circ} \mathrm{C}$, while the inlet air temperature was $27^{\circ} \mathrm{C}$. Heat discharged $Q_{\text {out }}$, i.e. at point $5 \mathrm{a}-1$ in the graph of Figure 3, was then used for the next cycle below (bottoming cycle) as the heat input in the HRSG unit.

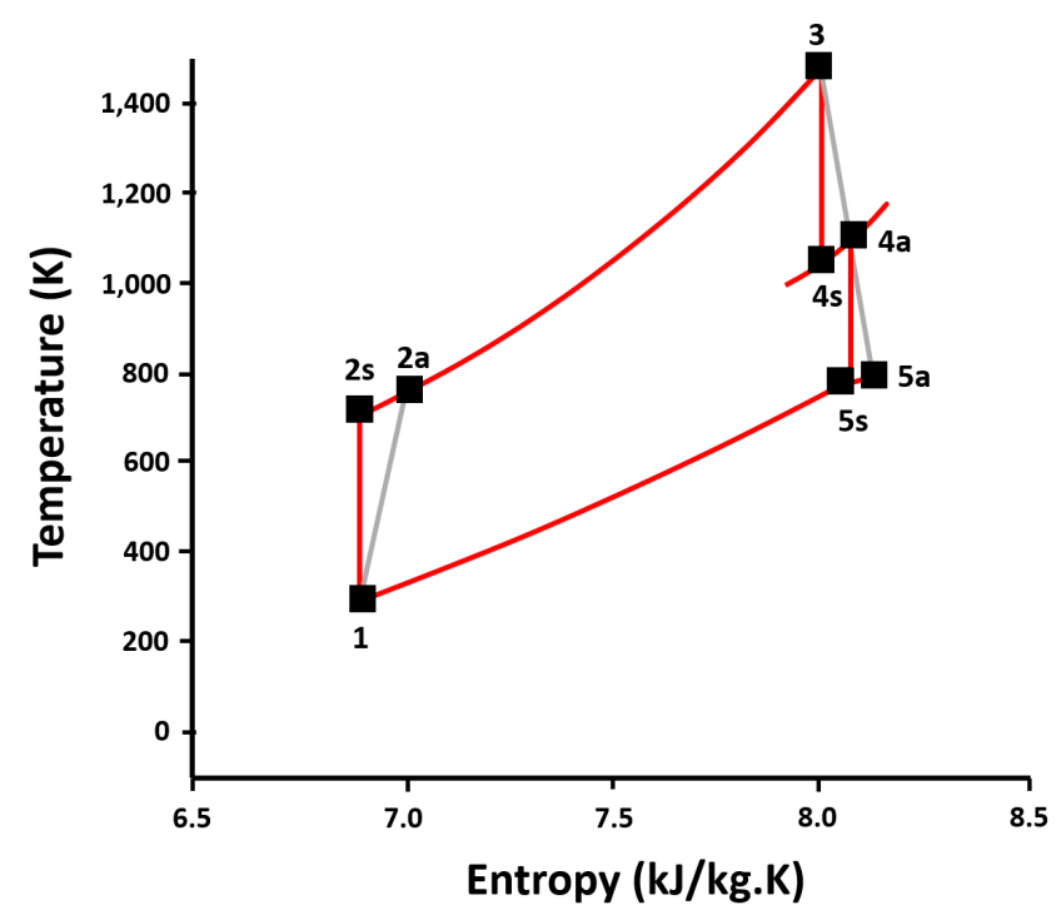

Figure 3. T-s diagram for the actual gas turbine cycle of the designed system.

In Figure 4 can be seen the Q-T diagram for the heat recovery steam generator (HRSG) at maximum loading. The inlet temperature of the working fluid was $120^{\circ} \mathrm{C}$, while the exhaust gas temperature of the gas turbine was $530^{\circ} \mathrm{C}$. The upper terminal difference was $30^{\circ} \mathrm{C}$, and the value of the pinch point temperature was $25^{\circ} \mathrm{C}$. The exhaust gas was released into the environment through a stack at a temperature of $198^{\circ} \mathrm{C}$.

In this design power generation cycle, as can be seen in Figure 5, the incoming heat $\left(Q_{\text {in }}\right)$ was heat taken from the gas turbine exhaust gas. Point 1-2 is the work of the pump (feed water pump). Then the water was pumped into the HRSG system. Point 2-3 is an economizer component that acts as a preheater. Water increased in temperature but was still in the saturated liquid phase. Then point 3-4 is the heat transfer process in an evaporator component. Here, the working fluid changed its phase into saturated steam. Then point $4-5$ is a superheater. This system worked at a pressure of 25 bar. Point 5-6 is the un-isentropic expansion or work of the steam turbine. The inlet temperature in the steam turbine was $500{ }^{\circ} \mathrm{C}$ at the maximum loading of the gas turbine. 


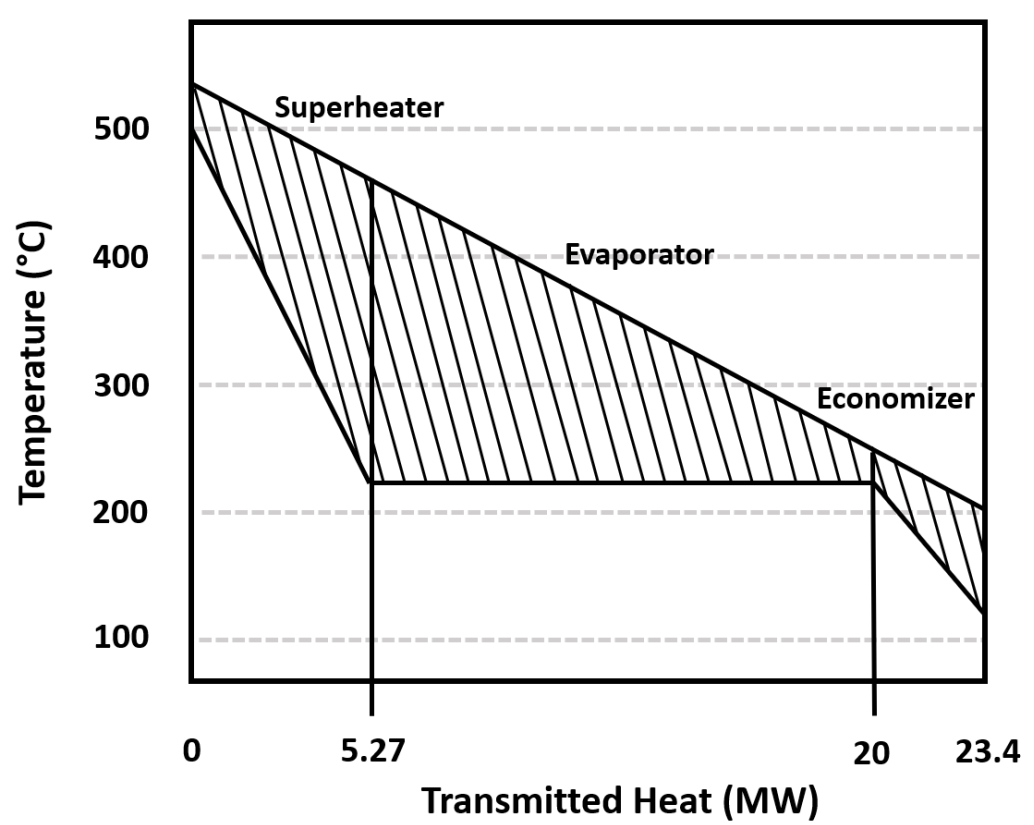

Figure 4. Q-T diagram for HRSG.

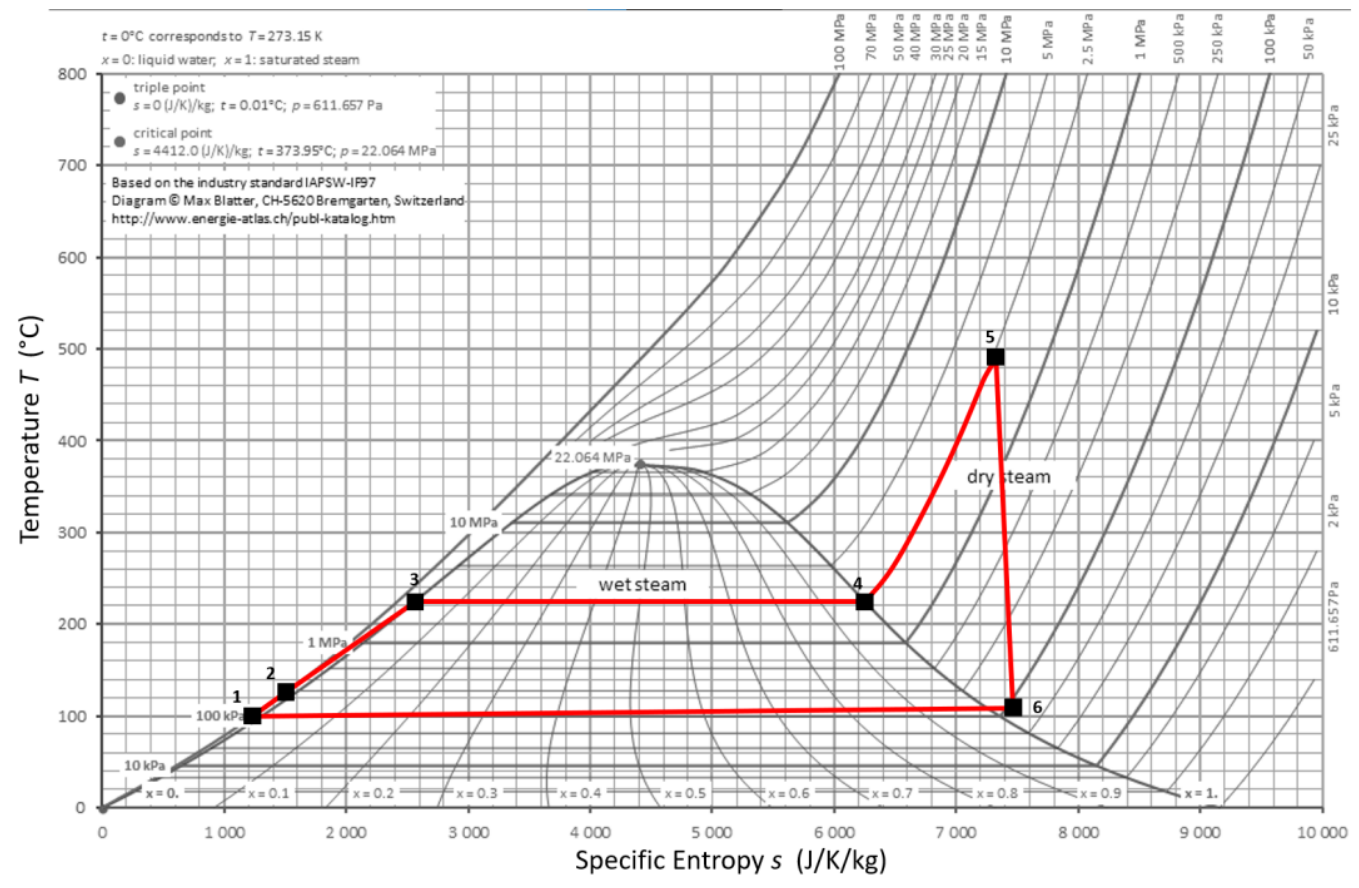

Figure 5. T-s diagram for the actual steam turbine cycle of the designed system.

\subsection{Analysis of System Performance}

In designing this propulsion system, energy supply only came from gas turbines, because there was no further combustion in the HRSG. Therefore, it is important in determining the performance limits of gas turbines because this can affect the bottom generation cycle. Gas turbines work in a relatively narrow range of performance that can be described in the performance curve of the axial compressor or axial turbine. Figure 6 is a graph plot of the variations of loading with pressure ratio to corrected mass flow of the LM 2500 gas turbine compressor. Gas turbines experience the phenomenon of surging when operated at a loading below $22.8 \%$, so this limit is a reference of gas turbine operations in the design of this system. In plotting the operating points in the performance curve, the designer must consider the magnitude of the mass flow rate and pressure ratio. The blue line represents the 
constant isentropic efficiency line so that keeping the operating point at a high-efficiency value can result in a more efficient system.

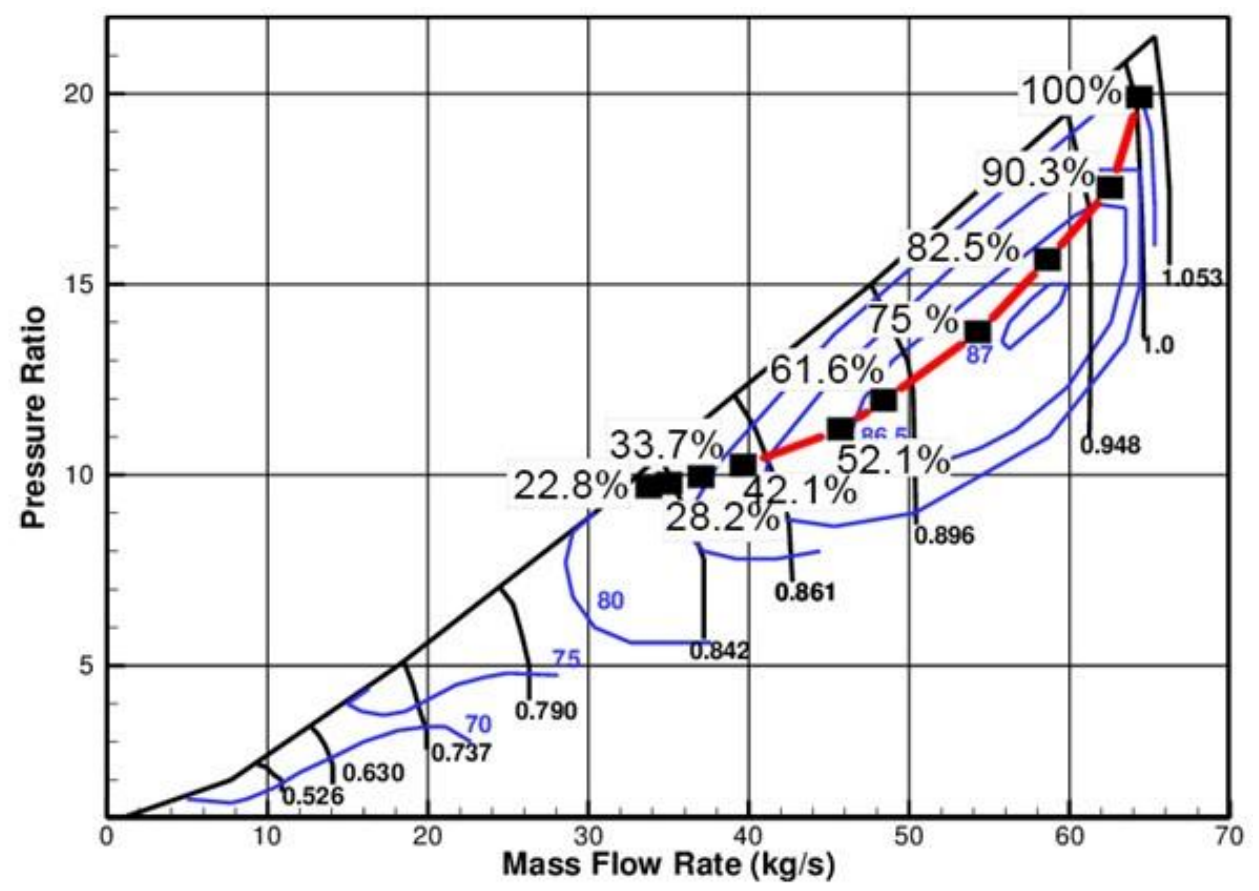

Figure 6. Plot curve performance of the LM 2500 gas turbine compressor against variations in loading from the system.

\subsection{Data Analysis of Simulation Results}

Based on data obtained from software simulation results, a graph is made to facilitate the drawing of conclusions from the observed data. Figure 7 presents a graph that shows the propulsion power at every percentage of the load of the engines, which can be seen the gas turbine engine become more dominant as the load increases. The gas turbine was taken as the reference for loading since it was the source of the overall heat system. The load or load percentage is the generated power of the gas turbine compared to the maximum power of the gas turbine. The total propulsion power of the system is the summation of the steam turbine power and the gas turbine power so that the value of the maximum total power of the system was $28,122.23 \mathrm{~kW}$ and the minimum power of the system was $6990.9 \mathrm{~kW}$. The limits of minimum loading were discussed in the previous subchapter. From the relationship between power and load, it could be seen that the power of the steam turbine decreased significantly at $33.77 \%$ loading. So, also be seen that the overall system power was decreased slightly. However, the rest of the total power needed was fulfilled by the power generated from the gas turbine.

Figure 8 shows that the total power efficiency follows on the gas turbine efficiency since the power of the steam turbine unit were relative constant at higher power load. The power efficiency is the total power of the gas turbine and steam turbine divided by the LHV fuel combustion power which is occur only in the gas turbine combustion chamber. Also, the maximum total propulsion system efficiency is at $48.49 \%$ at the maximum loading. This total efficiency will decrease as the loading percentage decrease. At minimum load, the total system efficiency is just $34.03 \%$. Gas turbine characteristics have best performance at the high design load. So, therefore part loading of the propulsion system causes the efficiency system to significantly decrease, along with the decrease of the performances of both the gas turbine and the steam turbine engines. The steam cycle, which gets heat from the gas turbine exhaust gas, experiences a decrease in performance due to reducing mass flow rate and the exhaust gas temperature of the gas turbine low load. 


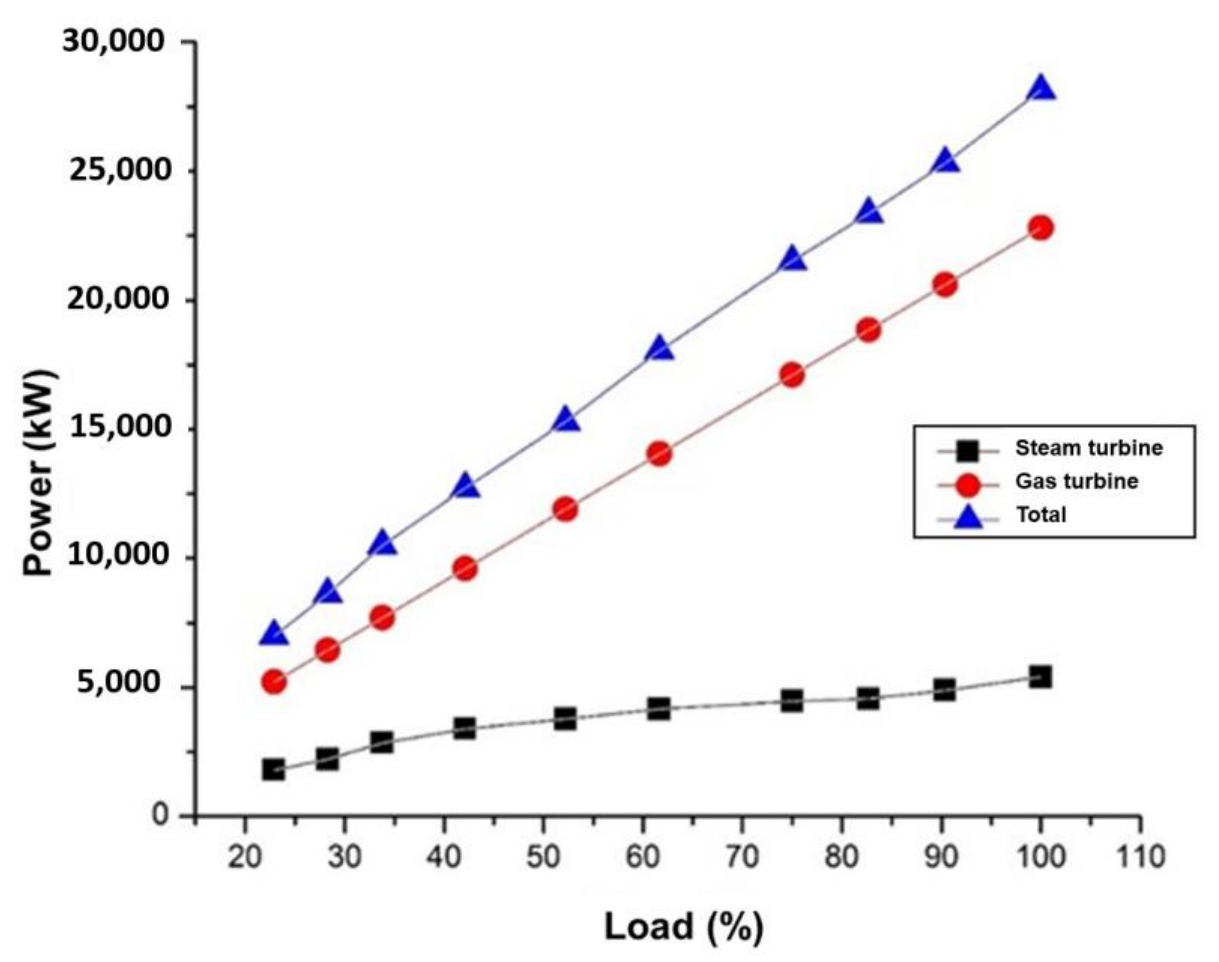

Figure 7. Power to the loading of the propulsion system.

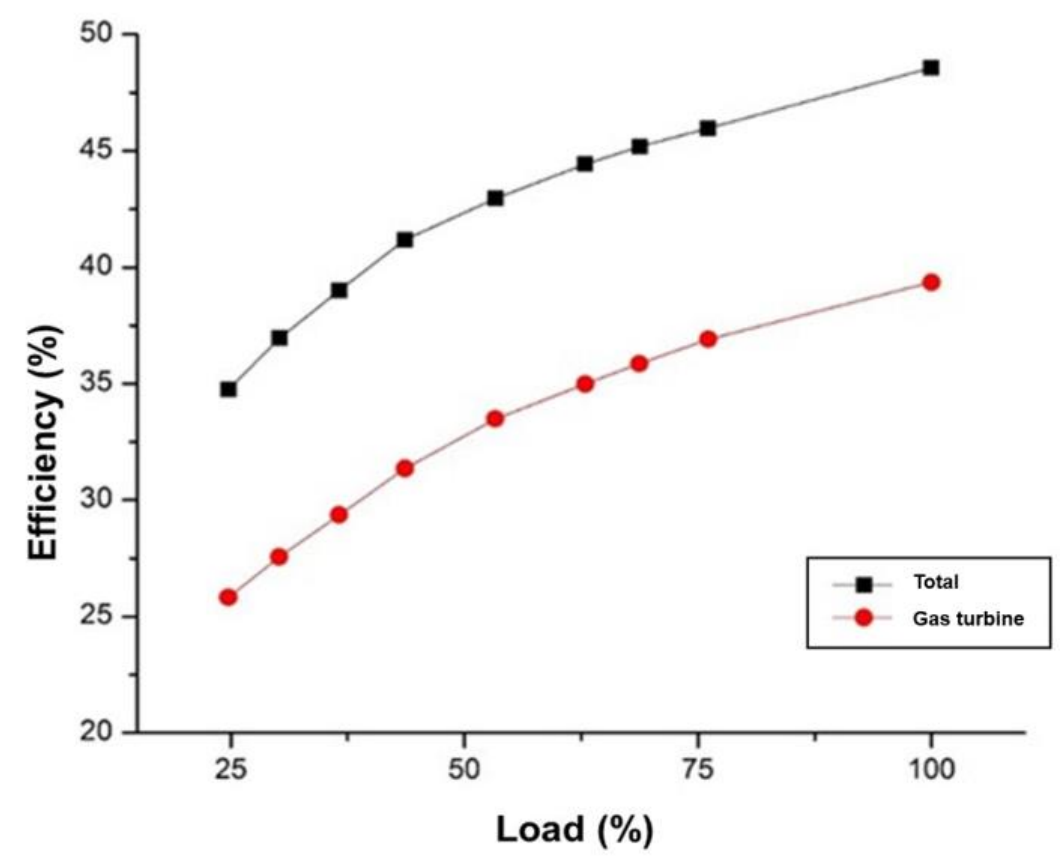

Figure 8. Efficiency of the system versus engine load.

Figure 9 explains the relationship between the load of the system and the speed that can be achieved by the ship. This simulation was carried out on the conditions of an empty ship or ballast condition as well as the ship at loaded condition. Both conditions are at maximum propulsion power loading. The loaded condition ship which is containing the cargo can reach a maximum speed of 20.67 knots, whereas for the ballast condition ship which is not containing a cargo can reach a maximum speed of 21.7 knots. Both at maximum propulsion power load. 


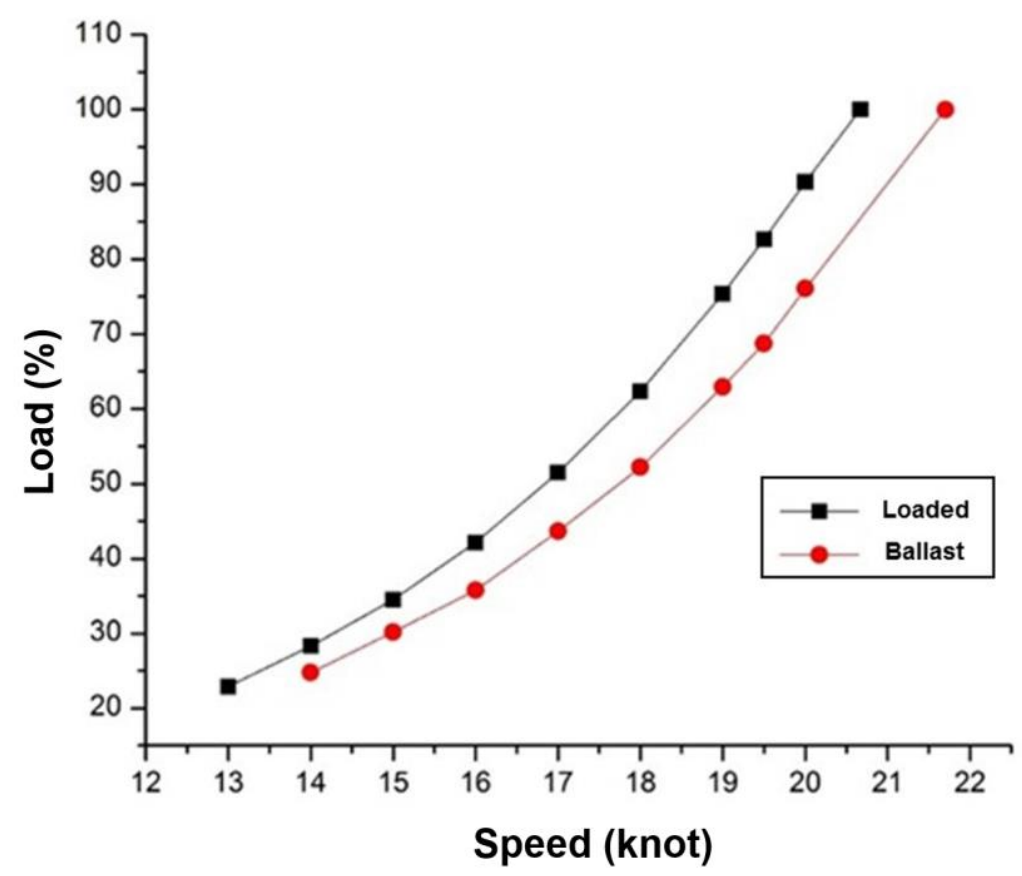

Figure 9. Graph of loading of the system and ship speed.

In Figure $10 \mathrm{a}$ and $\mathrm{b}$, it can be seen that the relationship between the required fuel consumption and the boil-off gas availability in LNG vessels, at the time of fully loaded cargo delivery (a) and when returning to port for loading (b). Based on the simulation results, there is no problem on the fuel consumption at the cargo delivery conditions ship. However if the ship sails on low speed, some considerations must be taken to anticipate problems from the increasing of the boil-off gas producing in the cargo space due to the lower fuel consumption with longer journey time. For loaded conditions ship to the destination port, the fuel availability from the boil-off gas produced in shipping will be $725,788.8 \mathrm{~kg}$ at maximum speed, whereas at lower speed of 13 knots, will be 1,154,004.3 kg. Then there will be differences of residual boil-off gas that was not consumed as engine fuel. It will be $235,896.2 \mathrm{~kg}$ after maximum speed sailing and $877,524.32 \mathrm{~kg}$ after sailing speed of 13 knots.
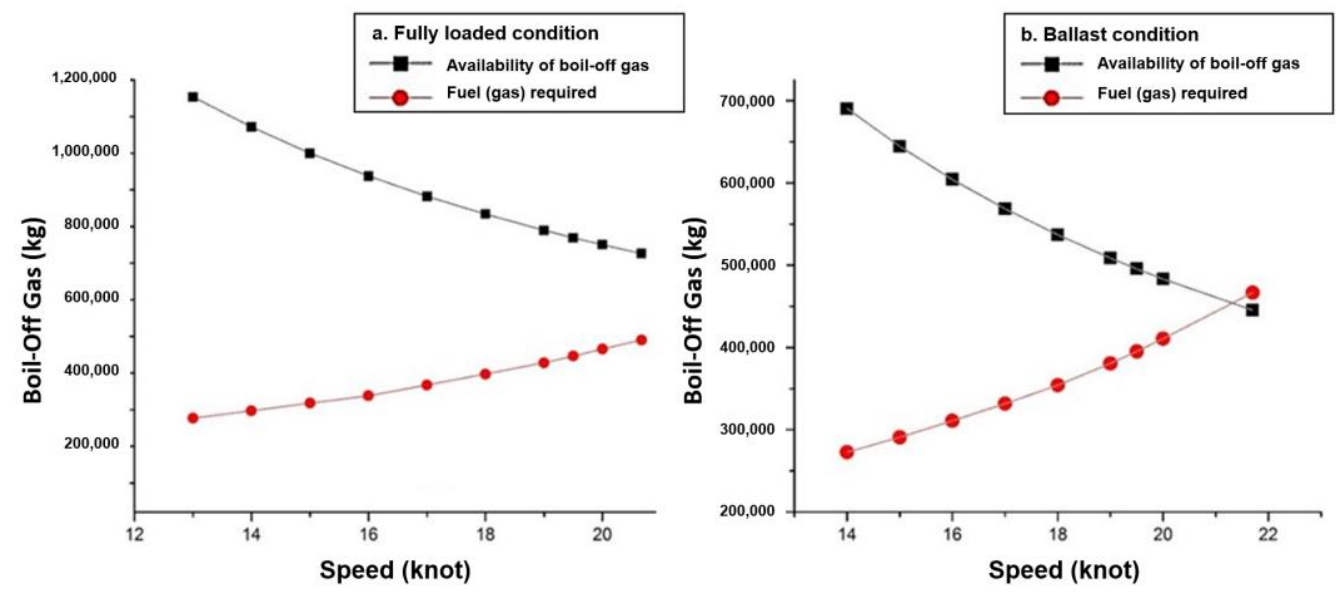

Figure 10. Availability of boil-off gas and fuel requirements of ships at the time of fully loaded condition (a) and ballast condition (b).

For empty ship conditions or ballast conditions with maximum sailing speed, the fuel needed during the cruise is $466,639.6 \mathrm{~kg}$, while the available boil-off gas will be $445,401.7 \mathrm{~kg}$. The fuel consumption will exceed the producing of availability of boil-off gas in the cargo. So, therefore a sailing speed selection is important for maintaining the fuel availability for ship. At a speed of 20 knots, 
for fully loaded condition ship the propulsion system fuel requirements is $488,320.86 \mathrm{~kg}$, whereas for ballast condition ship the needed fuel consumption is $410,832 \mathrm{~kg}$. This shows that the choice of speed and load of the engine greatly affects the producing availability of boil-off gas for engine fuel.

\section{Conclusions}

In this study, the design of the combined-cycle propulsion system was carried out on an LNG tanker with analytical calculation and simulation approaches using the Cycle-Tempo software. Combined cycle was used in the LNG tanker propulsion system with COGES (combined gas-electric steam) turbine configuration with the main components: gas turbine, steam turbine, heat recovery steam generator (HRSG), condenser, pump, deaerator, and generator. In accordance with the limits of gas turbine performance on the compressor performance characteristic map, gas turbines have a minimum loading limit of $22.8 \%$ due to the limits of the surge line. The maximum temperature of the gas turbine cycle at maximum loading is $1,215.87^{\circ} \mathrm{C}$ with a flue gas temperature of $530^{\circ} \mathrm{C}$, and the inlet pressure on the steam turbine is 25 bar. From the simulation results, the maximum power from the resulting system was $28,139.25 \mathrm{~kW}$. With the maximum power, the ship can cruise with a maximum speed of $20.67 \mathrm{knots}$ at fully loaded conditions and 21.7 knots at ballast ship conditions. There is a maximum speed difference of 1.03 knots between fully loaded conditions and ballast conditions. In addition, the availability of fuel from boil-off gas in shipping to the port of destination is calculated to be $725,788.8 \mathrm{~kg}$ at maximum speed, while at a speed of $13 \mathrm{knots}$ is 1,154,004.3 kg. There are residual boil-off gas differences that are not utilized as engine fuels of $235,896.2 \mathrm{~kg}$ at maximum speed and $877,524.32 \mathrm{~kg}$ at a speed of 13 knots. From the results, it can be concluded that the combined-cycle propulsion system using boil-off gas is feasible for LNG vessels. From the designed system, at fully loaded conditions, a maximum power of the system of about $28,122.23 \mathrm{~kW}$ is obtained with fuel consumption of about $1.173 \mathrm{~kg} / \mathrm{s}$, system efficiency of about $48.49 \%$ and the vessel speed can be reached up to 20.67 knots as well.

Author Contributions: Conceptualization, W.N., M.A.B. and R.M.; methodology, W.N., M.A.B. and R.M.; software, W.N., M.A.B. and R.M.; validation, W.N., M.A.B. and R.M.; formal analysis, W.N., M.A.B. and R.M.; investigation, W.N., M.A.B. and R.M.; resources, W.N.; data curation, W.N., M.A.B. and R.M.; writing-original draft preparation, W.N., R.M.; writing—review and editing, W.N., M.A.B.; visualization, W.N., M.A.B.; supervision, W.N.; project administration, W.N., M.A.B.; funding acquisition, W.N., M.A.B. All authors have read and agreed to the published version of the manuscript.

Funding: The research received only internal funding from the University of Indonesia as a research grant UI/PUTI Q2/2020 program number NKB-1683/UN2.RST/HKP.05.00/2020.

Acknowledgments: The authors would like to express their gratitude to the Directorate Research and Development of Universitas Indonesia (DRPM UI) for the grant support. This paper and its publication are supported by the UI/PUTI Q2/2020 program number NKB-1683/UN2.RST/HKP.05.00/2020. The authors also thank the Department of Mechanical Engineering at Universitas Indonesia for providing the supporting facilities during the research.

Conflicts of Interest: The authors are declaring that there are no conflicts of interests in this research. The funders, i.e., the University of Indonesia, had no role in the design of the study; in the collection, analyses, or interpretation of data; in the writing of the manuscript, or in the decision to publish the results.

\section{References}

1. Javanmardi, J.; Nasrifar, K.; Najibi, S.; Moshfeghian, M. Economic evaluation of natural gas hydrate as an alternative for natural gas transportation. Appl. Therm. Eng. 2005, 25, 1708-1723. [CrossRef]

2. Brito, A.; de Almeida, A.; de Almeida, A.T. Multi-attribute risk assessment for risk ranking of natural gas pipelines. Reliab. Eng. Syst. Saf. 2009, 94, 187-198. [CrossRef]

3. Folga, S.M. Natural Gas Pipeline Technology Overview; Argonne National Lab: Argonne, IL, USA, 2007. [CrossRef]

4. Montiel, H.; Vílchez, J.A.; Arnaldos, J.; Casal, J. Historical analysis of accidents in the transportation of natural gas. J. Hazard. Mater. 1996, 51, 77-92. [CrossRef]

5. Budiyanto, M.A.; Riadi, A.; Buana, I.S.; Kurnia, G. Study on the LNG distribution to mobile power plants utilizing small-scale LNG carriers. Heliyon 2020, 6, e04538. [CrossRef] 
6. Bennett, C.P. Marine Transportation of LNG at Intermediate Temperature; Springer: Boston, MA, USA, 1980; pp. 751-756. [CrossRef]

7. Wagner, J.V.; Van Wagensveld, S. Marine Transportation of Compressed Natural Gas a Viable Alternative to Pipeline or LNG. In Proceedings of the SPE Asia Pacific Oil \& Gas Conference and Exhibition, Society of Petroleum Engineers, Melbourne, Australia, 8-10 October 2002. [CrossRef]

8. Stenning, D.G.; Cran, J.A. Ship Based System for Compressed Natural Gas Transport. 1997. Available online: https://patents.google.com/patent/US5803005A/en (accessed on 20 January 2020).

9. Feng, L.; Shuanshi, F. Transmission and economy of shipping NGH. Tsinghua Tongfang Knowl. Netw. 2005, 7. Available online: http://en.cnki.com.cn/Article_en/CJFDTOTAL-TRQG200507043.htm (accessed on 20 January 2020).

10. Sinor, J.; Consultants, J. Comparison of CNG and LNG Technologies for Transportation Applications; Department of Energy: Golden, CO, USA, 1992. [CrossRef]

11. Maxwell, D.; Zhu, Z. Natural gas prices, LNG transport costs, and the dynamics of LNG imports. Energy Econ. 2011, 33, 217-226. [CrossRef]

12. International Gas Union. 2018 World LNG Report; International Gas Union: Barcelona, Spain, 2018. Available online: https://www.igu.org/sites/default/files/node-document-field_file/IGU_LNG_2018_0.pdf (accessed on 20 January 2020).

13. The Oxford Institute for Energy Studies. The LNG Shipping Forecast: Costs Rebounding, Outlook Uncertain; The Oxford Institute for Energy Studies: Oxford, UK, 2018. Available online: https://www.oxfordenergy.org/wpcms/wp-content/uploads/2018/02/The-LNG-Shipping-Forecastcosts-rebounding-outlook-uncertain-Insight-27.pdf (accessed on 20 January 2020).

14. Mrzljak, V.; Poljak, I.; Mrakovčić, T. Energy and exergy analysis of the turbo-generators and steam turbine for the main feed water pump drive on LNG carrier. Energy Convers. Manag. 2017, 140, 307-323. [CrossRef]

15. Pamitran, A.S.; Budiyanto, M.A.; Maynardi, R.D.Y. Analysis of ISO-Tank Wall Physical Exergy Characteristic: Case Study of LNG Boil-off Rate from Retrofitted Dual Fuel Engine Conversion. Evergreen 2019, 6, 134-142. [CrossRef]

16. Haglind, F. A review on the use of gas and steam turbine combined cycles as prime movers for large ships. Part II: Previous work and implications. Energy Convers. Manag. 2008, 49, 3468-3475. [CrossRef]

17. Senary, K.; Tawfik, A.; Hegazy, E.; Ali, A. Development of a waste heat recovery system onboard LNG carrier to meet IMO regulations. Alex. Eng. J. 2016, 55, 1951-1960. [CrossRef]

18. Attah, E.E.; Bucknall, R. An analysis of the energy efficiency of LNG ships powering options using the EEDI. Ocean Eng. 2015, 110, 62-74. [CrossRef]

19. Budiyanto, M.A.; Pamitran, A.S.; Wibowo, H.T.; Murtado, F.N. Study on the Performance Analysis of Dual Fuel Engines on the Medium Speed Diesel Engine. J. Adv. Res. Fluid Mech. Therm. Sci. J. 2020, 68, 163-174. [CrossRef]

20. Fernández, I.A.; Gómez, M.R.; Gómez, J.R.; Insua, Á.B. Review of propulsion systems on LNG carriers, Renew. Sustain. Energy Rev. 2017, 67, 1395-1411. [CrossRef]

21. Chang, D.; Rhee, T.; Nam, K.; Chang, K.; Lee, D.; Jeong, S. A study on availability and safety of new propulsion systems for LNG carriers. Reliab. Eng. Syst. Saf. 2008, 93, 1877-1885. [CrossRef]

22. Sinha, R.P.; Nik, W.M.N.W. Investigation of propulsion system for large LNG ships. In Proceedings of the 1st International Conference on Mechanical Engineering Research 2011 (ICMER2011), IOP Conference Series: Materials Science and Engineering, Kuantan, Pahang, Malaysia, 5-7 December 2011; pp. 1-16. [CrossRef]

23. Haglind, F. A review on the use of gas and steam turbine combined cycles as prime movers for large ships. Part III: Fuels and emissions. Energy Convers. Manag. 2008, 49, 3476-3482. [CrossRef]

24. Lee, D.-M.; Kim, S.-Y.; Moon, B.-Y.; Kang, G.-J. Layout design optimization of pipe system in ship engine room for space efficiency. J. Korean Soc. Mar. Eng. 2013, 37, 784-791. [CrossRef]

25. Budiyanto, M.A.; Nasruddin; Nawara, R. The optimization of exergoenvironmental factors in the combined gas turbine cycle and carbon dioxide cascade to generate power in LNG tanker ship. Energy Convers. Manag. 2020, 205, 112468. [CrossRef]

26. Hansen, J.F.; Lysebo, R. Comparison of Electric Power and Propulsion Plants for LNG Carriers with Different Propulsion Systems. 2007. Available online: http://www.dieselduck.info/machine/02propulsion/ 2007ComparisonLNGcarrierpropulsion.pdf (accessed on 20 January 2020).

27. Wiggins, E.G. COGAS propulsion for LNG ships. J. Mar. Sci. Appl. 2011, 10, 175-183. [CrossRef] 
28. Dimopoulos, G.; Frangopoulos, C. Thermoeconomic Simulation of Marine Energy Systems for a Liquefied Natural Gas Carrier. Int. J. Thermodyn. 2008, 11, 195-201. Available online: https://dergipark.org.tr/en/pub/ ijot/issue/5770/76768 (accessed on 20 January 2020).

29. Jefferson, M.; Zhou, P.L.; Hindmarch, G. Analysis by computer simulation of a combined gas turbine and steam turbine (COGAS) system for marine propulsion. J. Mar. Eng. Technol. 2003, 2, 43-53. [CrossRef]

30. Oka, M.; Kazuyoshi, H.; Kenji, T. Development of Next-Generation LNGC Propulsion Plant and HYBRID System. MHI Tech. Rev. 2004, 41. Available online: http://www.mhi.co.jp/technology/review/pdf/e416/ e416322.pdf (accessed on 20 January 2020).

31. Hanochem Shipping, LNG AQUARIUS. Available online: http://www.gts-internasional.com/lng-aquarius (accessed on 20 January 2020).

32. Cuneo, J. Service Experience with $125.000 \mathrm{~m}^{3}$ LNG Vessel of Spherical-Tank Design. Soc. Nav. Arch. Mar. Eng. Trans. 1980, 88. Available online: https://www.sname.org/pubs/journals1 (accessed on 20 January 2020).

33. BMKG. Meteorology, Climatology, Data Online Center Database. Available online: http://dataonline.bmkg. go.id/home (accessed on 16 July 2019).

34. Bentley Systems, Maxsurf 20.00 V8i Release Notes-MAXSURF|MOSES|SACS—Wiki-MAXSURF|MOSES| SACS-Bentley Communities. Available online: https:/communities.bentley.com/products/offshore/w/wiki/ 14169/maxsurf-20-00-v8i-release-notes (accessed on 21 January 2020).

35. Garjito, A.; Sumarno, A. Indonesia LNG and the Badak Plant; Indonesian Petroleum Association: South Jakarta, Indonesia, 1981; pp. 459-474. Available online: http://archives.datapages.com/data/ipa/data/010/010001/459_ ipa0100459.htm (accessed on 20 January 2020).

36. Aviation, G.E. Marine Gas Turbine. 2014. Available online: https://www.geaviation.com/sites/default/files/ datasheet-25mw.pdf (accessed on 15 January 2020).

37. Asimptote, B.V. Cycle-Tempo Manual Technical Notes. Available online: http://www.asimptote.nl/assets/ media/7d155f62-ffe2-4a9e-9f33-bb003c80bd2b.pdf (accessed on 20 January 2020).

38. Følgesvold, E.R.; Skjefstad, H.S.; Riboldi, L.; Nord, L.O. Combined Heat and Power Plant on Offshore Oil and Gas Installations. 2011. Available online: http://papers.itc.pw.edu.pl/index.php/JPT/article/view/842 (accessed on 20 January 2020).

39. Saravanamuttoo, H.I.; Rogers, G.F.; Cohen, H. Gas Turbine Theory; Addison-Wesley Longman: Boston, MA, USA, 1996. 